UDC 378.018 .43

DOI https://doi.org/10.32782/tps2663-4880/2021.17-2.14

\title{
THE PECULIARITIES OF LANGUAGE PORTFOLIO IMPLEMENTATION IN THE TEACHING PROCESS
}

\section{ОСОБЛИВОСТІ ВПРОВАДЖЕННЯ МОВНОГО ПОРТФОЛІО В НАВЧАЛЬНИЙ ПРОЦЕС}

\author{
Chugai O.Yu. \\ orcid.com/0000-0002-2118-8255 \\ Candidate of Pedagogical Sciences, \\ Associate Professor at the Department of Technical English № 2 \\ National Technical University of Ukraine "Igor Sikorsky Kyiv Polytechnic Institute"
}

Yamshynska N.V.,
orcid.org/0000-0002-0518-3657
Lecturer at the Department of Technical English № 2
National Technical University of Ukraine "Igor Sikorsky Kyiv Polytechnic Institute"
Svyrydova L.H.,
orcid.org/0000-0002-9762-4092
National Technical University of Ukraine "Igor Sikorsky Kyiv Polytechnic Institute"
Lecturer at the Department of Technical English № 2
Kutsenok N.M.,
orcid.org/0000-0001-7111-0088
National Technical University of Ukraine "Igor Sikorsky Kyiv Polytechnic Institute"”

Modern world is full of capabilities for people to learn and develop specific skills to be successful in different spheres of life. For instance, language awareness offers a unique opportunity for everyone to be a competent employee who can solve various specific field-related tasks due to professional knowledge and communication skills. New technologies, various methods and instruments have unlimited potential for teachers to equip their students with a whole set of language skills to meet the standards of The Common European Framework of Reference for Languages (CEFR).

The article is focused on language portfolio as one of the tools, which provide both a teacher and a student with current information about a student's progress during the studying period and can guarantee a true assessment of his/her achievements. The authors consider language portfolio as an effective instrument for personal growth of students. The article discusses structural components of language portfolio, its types and ways of implementation in the learning process.

The analyses of the literature showed that the attention of a lot of scientists and education specialists were drawn to this instrument as one which could provoke further development of a person's language skills. The authors of the article came to the conclusion that the language portfolio is designed to give a positive impact on the quality of the teaching process especially if it concerns language acquisition.

The research was conducted with the aim to define the main motivating factors for students in preparing the language portfolio, their attitude to it and as a result to offer teachers to use such a tool as language portfolio more widely in their practice in order to make the teaching process more interesting and productive.

The research showed that students are ready to be involved in the process of preparing a language portfolio because they understand the importance of it for their career promotion. They agree that due to the language portfolio they get full information about the level of their language proficiency, which can be showed to the potential employer. The authors had a goal to raise the awareness of teachers about this effective instrument, show all its benefits and expand its popularity in the higher educational establishments.

Key words: European Language Portfolio, assessment tool, systematic assessment process, students' achievements, language efficiency, students' motivation, language skills, student's self-reflection.

Сучасний світ надає багато можливостей людям навчатися і розвивати свої навички для досягнення успіху у різних сфрерах життя, а володіння іноземними мовами розширює простір для зростання особистості у професійній сфрері будь-якої галузі суспільства для вирішення професійно орієнтованих завдань, завдяки професійним знанням і комунікативним навичкам. Новітні технології, різні методи та інструменти допомагають як викладачам, так і студентам, подолати труднощі навчального процесу, набути мовних навичок, щоб відповідати стандартам Спільної європейської системи мов (CEFR). Стаття представляє мовномне портфоліо як один з інструментів, який, по-перше, у цікавому доступному форматі надає інформацію про успіхи протягом періоду навчання, по-друге, сприяє реальному оцінюванню та досягненню студентів. Автори статті розглядають мовне портфоліо як ефективний інструмент особистісного зростання студентів, його структурні компоненти, типи та шляхи впровадження у навчальний процес. Аналіз літератури показав, що багатьох науковців та освітян цікавить саме мовне портфоліо у процесі розвитку мовних навичок. Автори статті дійшли висновку, що мовне портфоліо має позитивний вплив на якість навчального процесу, особливо під час навчання та викладання іноземної мови. Дослідження проведено з метою визначення основних мотиваційних 
факторів для студентів під час підготовки мовного портфоліо, їх ставлення до нього та, як наслідок, запропонувати викладачам можливість використовувати такий інструмент у своїй практиці, щоб зробити навчальний процес більш цікавий і продуктивним. Дослідження також показало, що студенти зацікавлені брати участь у процесі підготовки мовного портфоліо, розуміють його важливість для подальшого зростання у професійній сфрері і можливість застосування у майбутньому житті. Студенти вважають, що завдяки мовному портфоліо вони отримують повну інформацію про своє знання мови, бачать шляхи вдосконалення навичок та можуть оцінити набуті досягнення. Автори ставлять за мету підвищити обізнаність викладачів про те, що таке мовне портфоліо, показати його переваги та застосування під час навчального процесу у вищих навчальних закладах.

Ключові слова: європейське мовне портфоліо, інструмент оцінювання, систематичний процес оцінювання, досягнення студентів, мовна ефективність, мотивація студентів, мовні навички, саморефрлексія студента.

Introduction. Future specialists at higher educational establishments are provided with a set of soft skills, which are thought to be the main attributes of a successful person and are needed for making efficient interaction at a workplace. Companies seek employees, who are ready to constantly obtain new knowledge and competencies to meet the demands of the modern business world. Therefore, people possessing a strong educational background and good communication skills will surely be hired and are able to get the job they want. That is why teaching and learning foreign languages are widely proved to be of priority for the educational system of each country. The era of digital technologies proposes a variety of new methods and techniques, which help teachers and students to combine their efforts to achieve main language curriculum goals. However, the issue of proper evaluation of students' achievements in learning a foreign language still exists. Assessment is known to be an integral part of any learning process because without the means of assessing the acquisition of knowledge, namely of foreign language, becomes non-productive. The evaluation shows the progress of each student at a particular stage of learning and advocates a way of motivating students. As a consequence, teachers are working on new, more effective methods of evaluation of students' achievements. It is crucial to have the information about the level of students' knowledge to be able to analyze possible gaps and plan further learning processes. It also gives a signal to the teacher how she/he can correlate the teaching process to help students to obtain qualitative education which should meet all standards of the Common European Framework of Reference for Languages (CEFR). The concept of the language portfolio, as a powerful tool for determining the level of foreign language acquisition, was developed by the Language Policy Department of the Council Europe. It has attracted considerable attention in the European educational space being characterized by multilingualism and multiculturalism.

Literature review. Many native and foreign methodologists have paid a lot of attention to the concept of language portfolio (LP) deriving the definition and principles of the LP. Following $Z$. Rao, the language portfolio is one of the effective instruments which "provides comprehensive information about students and provides feedback on students' performance" [1, p. 120]. J. Kemp and D. Toperoff define the portfolio as a "purposely collection of the student's effort, progress and success in one or more fields" [2]. According to the authors of "European Language Portfolio: proposals for development", the ELP is a tool to promote learner autonomy based on the following principles: the development of the language learner the development of the capacity for independent language learning transparency and coherence in language learning programs, and clear description of language competence and qualifications in order to facilitate mobility [3, p. 131]. One can mention that many categorizations have been applied in relevance with language portfolios.

The Principles and Guidelines approved by the Council of Europe proposed and described the following models of Language Portfolio:

- Language Passport where the language user documents his/her own language background, other languages that have been learned at school or outside school, and an overview of official diplomas, such as exam documents, language courses, and certificates;

- Language Biography, which consists of statements on language use, through which the language user can reflect on his/her proficiency in a specific language. The list of statements is related to the Common European Framework;

- Language File that is a combination of documents consisting of, for example, certified documents showing reports and studies the language user produced during the probation; the studies he/she made during a student exchange program if attended; and documents concerning a particular language used during his studies for projects and presentations he has participated in [4].

On the other hand, H. C. Barrett [5, p. 440] and G. Greenberg [6, p. 32] in their studies identified the three following types of portfolio: learning portfolio, presentation portfolio and evaluation 
portfolio, which can be used with different purposes but are focused on the main aim that is personal and professional development as well as the capacity for self-evaluation.

Among Ukrainian scientists, who investigated the concept of language portfolio, one can mention I. Zadorozhna, L. Martyniuk, T. Polonska, L. Danylenko, and others. They considered the language portfolio, its purpose, structure, types, the algorithm of its composition, while O.Karpiuk substantiated the implementation of the language portfolio in practice in Ukrainian educational establishments [7]. L. Danylenko [8] and O. Sapozhnykova [9] suggested the following criteria for evaluating the language portfolio, namely: availability of mandatory headings and conclusions; application of research methods; creative approach to the development of the portfolio, certain personal component, quality of design, the relevance of the portfolio, the reflection of student's activities in foreign language training.

T. Polonska examines the effectiveness of using the Ukrainian variant of the European Language Portfolio and makes it evident that this tool allows conducting an ongoing evaluation of the learning process, promotes learning autonomy and motivation [10].

D. Little in his study pointed out advantages of the language portfolios and claimed that language portfolios can stimulate reflective learning in which goal setting and self-assessment play a central role. Students become more autonomous in language learning in proportion as they become more autonomous in language use, and vice versa [11].

It is worth mentioning that all methodologists and linguists with one assent consider the language portfolio as an effective tool for motivating students to learn foreign languages in the context of a life-long perspective.

Purpose statement. From the analyses of the literature devoted to the problem of the language portfolios, it became clear that the necessity in carrying out the survey among teachers and students to reveal their demands as well as their attitude to this tool of stimulating further learning of the foreign language in students is urgent. Ukrainian society is open for changes and ready to meet both new challenges and demands. For this, people should constantly acquire new knowledge and skills, and think about their improvements and self-development. These are the key reasons why it is very significant for a person to be able to know educational background and assess his/her language abilities. The language portfolio is one of the instruments which does that. The aim of the research is to define the main motivating factors for students in preparing the language portfolio, their attitude to it and how teachers should act to make teaching more efficient.

Research results. The survey was conducted among 80 students of National Technical University of Ukraine "Igor Sikorsky Kyiv Polytechnic Institute" in March, 2021. The questions were focused on gathering information, which would be useful for increasing students' motivation for language learning and improving teaching strategies on how to make the process of collecting the language portfolio more inspiring for students.

The data gathered from the students' questionnaires has shown that $45 \%$ of students have had some experience in collecting language portfolios (fig. 1).

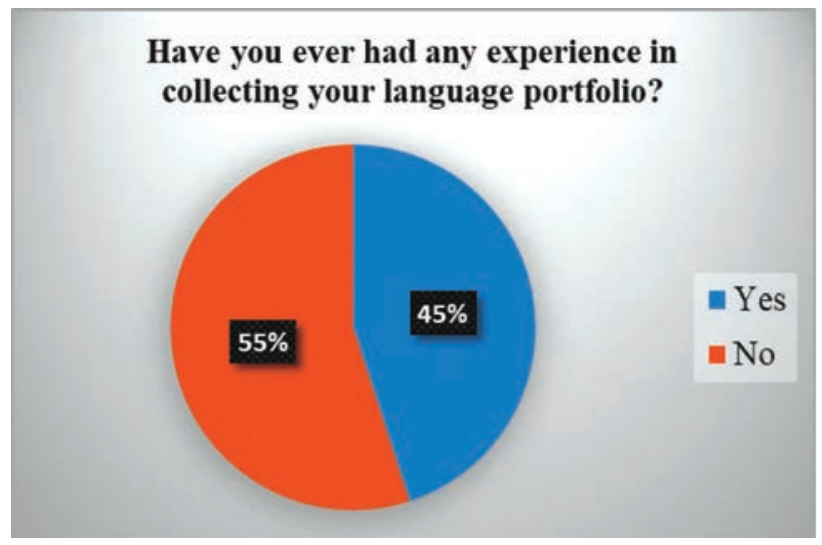

Fig. 1

It means that the majority of students (55\%) do not know exactly how to do this and do not even have enough knowledge about this tool. This fact confirms that teachers of secondary schools and universities should alter their teaching methods and pay more attention to those, which will guarantee the further promotion of students' language skills. The language portfolio will provide a correct estimate of the level of knowledge that a student possesses and will stimulate him/her to take their own learning initiatives following the learning targets and aims.

As for the reasons for students to collect the language portfolio, the majority of them (39\%) have chosen the variant that the language portfolio facilitates educational and vocational mobility (fig. 2). Their choice can be explained by the fact that the younger generation can choose any university to study and get high quality education, which will guarantee their future career promotion.

It is a real motivator for students to learn a foreign language and be able to apply their knowledge. That is why the language portfolio can facilitate their desire to expand their language barriers. 


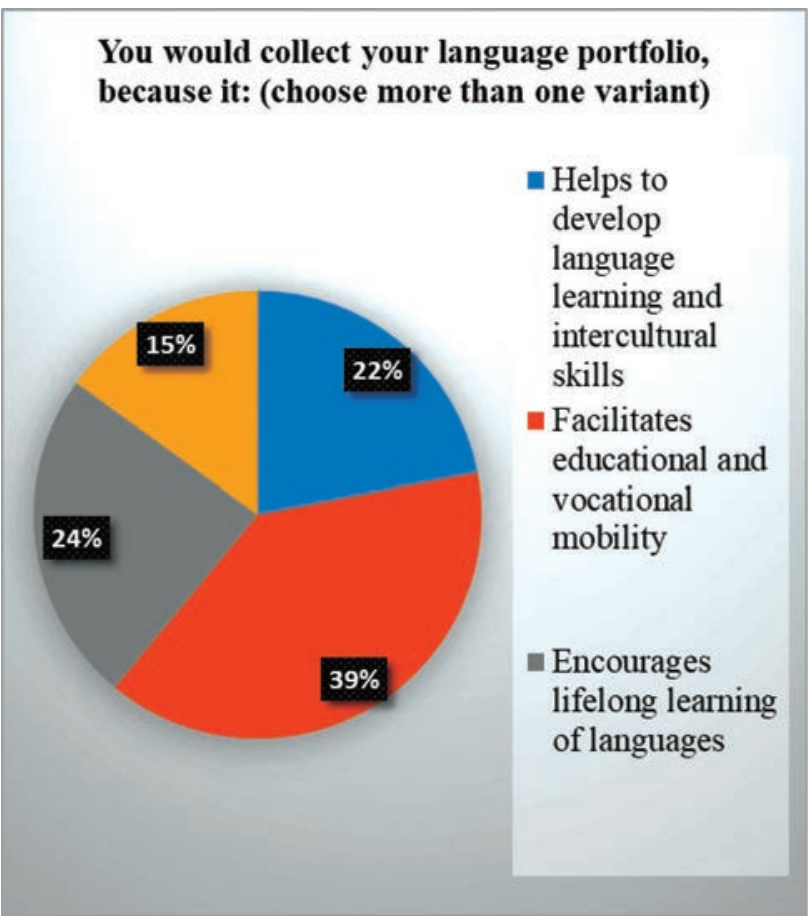

Fig. 2

The analysis of students' answers on the question as for the best way of introduction of the language portfolio confirms all the information above and the fact that students are becoming more and more oriented toward the European Education Area. Most of them (36\%) have chosen such options as explaining the reporting function, which opens the door to Europe for them and a little less (24\%) emphasizing the value of common European scales of proficiency (fig. 3).

These results should be taken into consideration by teachers at secondary schools and pedagogical staff at higher educational establishments in order to unite their efforts and prepare specialists who are able to meet the tough demands of modern society. Teachers educate a new generation and their impact is both valuable and significant. They should find and apply modern methods and techniques to provoke students to formulate their educational goals and make efforts to achieve them. The language portfolio can be considered as the backbone of students' personal responsibility.

The students' viewpoints on the value of different parts of the language portfolio are divided about equally between three parts (35\%, 32\%, 33\% correspondingly). Such division is expected and proves that the language portfolio is a mixer of all language learning experiences and achievements. While collecting their own language portfolios students are able to recognize that it is an instrument, which is useful "to fulfil the needs of the individuals in a society that sees learning as a lifelong process" (1). The complex language portfolio will serve as Your gateway to universities in Europe as well as a communication and assessment tool in conversations with prospective employers.

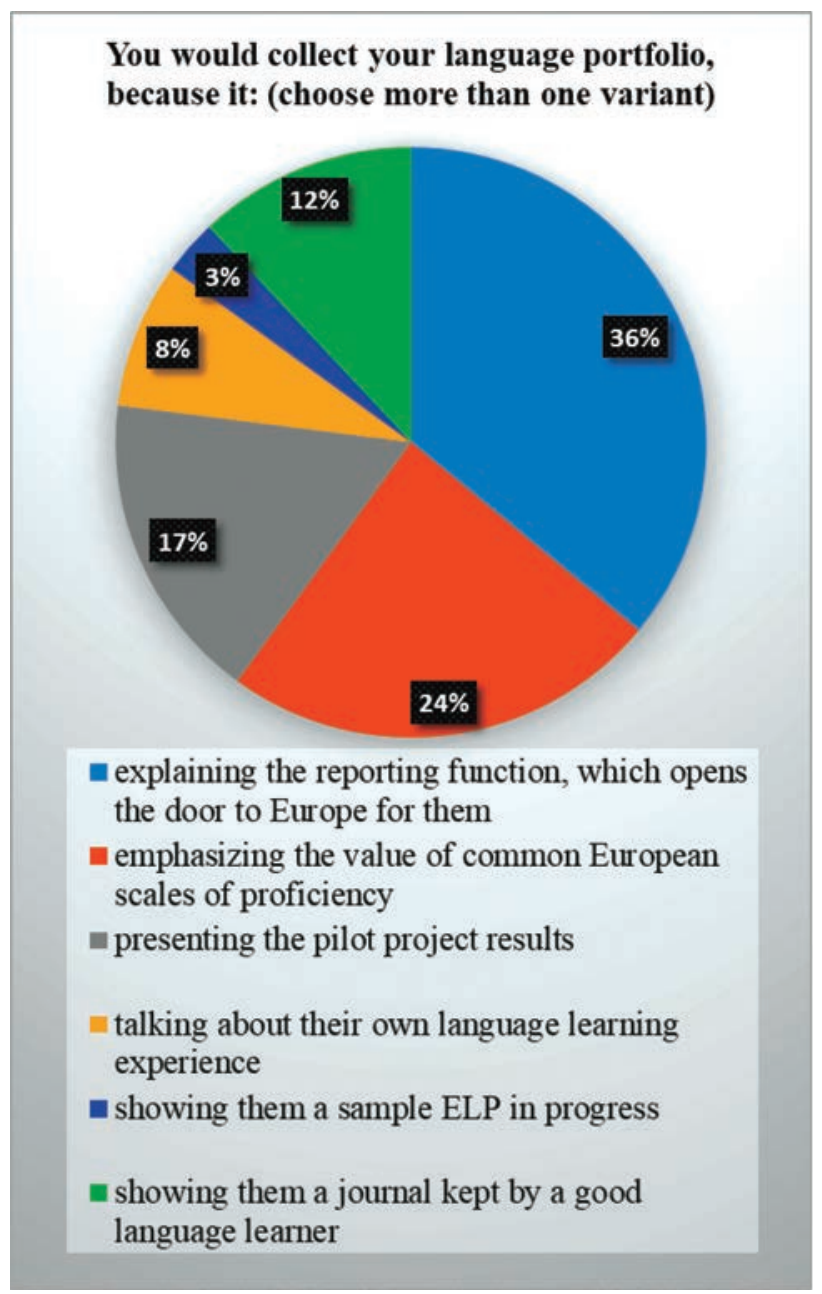

Fig. 3

The participants of the study have chosen portfolio $(23 \%)$, report $(20 \%)$ and essay (17\%) among others as the main types of productive activities, which will provide an effective module assessment (fig. 4).

Most of the students expressed their strong agreement $(43 \%)$ or agreement (50\%) with the statement that collecting ELP might enhance their motivation as well as modify foreign language learning stereotypes. Moreover, the majority of students (78\%) claimed the language portfolio would have an encouraging and inspiring impact on their personal and professional development. It correlates with M. Demirel and H. Duman studies outcomes, which showed students' favourability towards this activity [12]. N. Barootchi and M. H. Keshavarz also suggested the portfolio to be a technique having a positive influence on students' performance and thus, its effectiveness in the planning of foreign language curriculum [13]. 


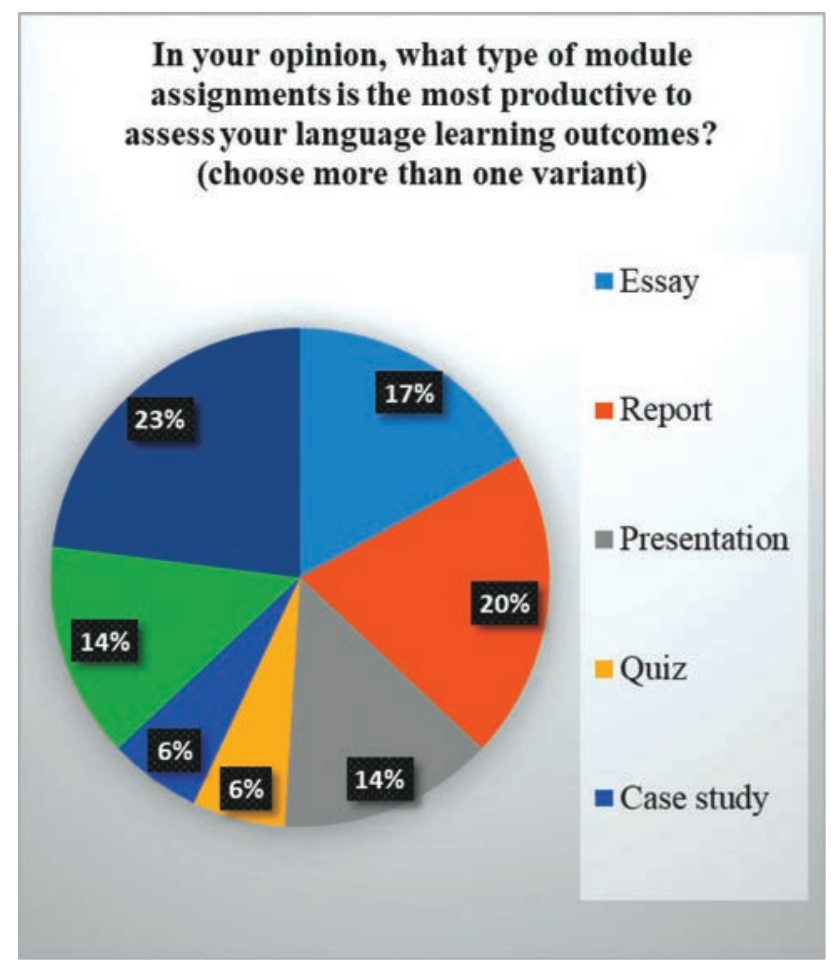

Fig. 4

Conclusions. The linguistic experts claim that the main practical aims of the foreign language teaching are to provide the learners with necessary language skills (writing, listening, speaking and reading), which ensure that the process of second language acquisition is efficient and purposeful. However, the process will not be complete without the possession of skills for self-development. Language awareness and language proficiency will make the learners effective participants of the communicative process. After the survey among students of National Technical University of Ukraine "Igor Sikorsky Kyiv Polytechnic Institute" the authors could conclude that a language portfolio would be useful for increasing students' motivation; correlate teaching strategies to make the studying process more inspiring for students; due to the language portfolio learners are able formulate and finally become focused on achieving the language targets. These options will provide students with required skills for their further professional growth. It is possible to sum up that language portfolio is considered to be a significant step towards social adaptability and professional growth of a person. It provides the possibility for a person to be a competent communicator who is able to speak the language fluently and accurately. Due to the language portfolio learners formulate and finally become focused on achieving the language targets. Based on the analyses of scientific literature and related research it becomes obvious that language portfolio among other methods and techniques of language teaching seems to be one of the most effective. It should be noted that a language portfolio performs the role of an assistant for students during the period of language studying which informs them about their achievements and proposes routes for development. It contributes to the development of language skills and finally language efficiency. Its encouraging and motivational effects are proved by the students' responses to the questions of the survey. Further investigations should be focused on finding more productive ways of portfolio implementation in the studying process aimed to facilitate students' language skills and preferences.

\section{REFERENCES:}

1. Rao Z. Helping Chinese EFL students develop learner autonomy through portfolios. Reflections on English Language Teaching. 2006. Vol. 5. № 2. P. 113-122.

2. Kemp J., Toperoff D. Guidelines for Portfolio Assessment in Teaching English. URL: http://www.anglit.net/ main/ portfolio/default.html

3. Council of Europe. Common European Framework of Reference for Languages: Learning, teaching, assessment. Strasbourg: Cambridge University Press, 1997. 273 p.

4. Council of Europe Common European Framework of Reference for Languages: Learning, Teaching, Assessment (CEFR). URL: https://www.coe.int/en/web/common-european-framework-reference-languages

5. Barrett H. C. Researching electronic portfolios and learner engagement: The REFLECT initiative. Journal of Adolescent \& Adult Literacy. 2007. Vol. 50. № 6. P. 436-449.

6. Greenberg G. The digital convergence: extending the portfolio model. Educause Review. Vol. 39. № 4. P. $28-36$. URL: http://net.educause.edu/ir/library/pdf/ERM0441.pdf

7. Карп'юк О. Європейське мовне портфоліо: методичне видання / О. Карп'юк. Тернопіль : Лібра Терра, 2008. 112 с.

8. Даниленко Л. Оцінювання та відбір педагогічних інновацій: теоретико-прикладний аспект : Науково-методичний посібник / за ред. Л. Даниленко. Київ : Логос, 2001. 185 с.

9. Сапожникова О.М. Метод мовного портфоліо як інструмент інноваційного навчання іноземних мов. Стратеаіі міжкультурної комунікації в мовній освіті сучасних університетів: збірник матеріалів VI міжнар. наук. конф.., III міжнар. наук. конгресу Society of Ambient Intelligence, м. Київ, 2-10 квітня 2020 р. Київ : КНЕУ, 2020. С. 184-186.

10. Polonska T. Language portfolio as an innovative component of teaching and learning complexes in a foreign language for senior schools. URL:http://undip.org.ua/upload/iblock/700/2_62.pdf

11. Little D. Learner autonomy 1: Definitions, issues and problems. Dublin: Authentik, 1991. 67 p.

12. Demirel M., Duman H. The Use of Portfolio in English Language Teaching and Its Effects on Achievement and Attitude. Procedia. Social and Behavioral Sciences. 2014. Vol. 191. № 2. P. 2634-2640.

13. Barootchi N., Keshavarz M. H. Assessment of achievement through portfolios and teacher-made tests. Educational Research. 2002. Vol. 44. № 3. P. 279-288. DOI:10.1080/00131880210135313 